\title{
JURNAL PENGABDIAN MASYARAKAT
}

\section{LEMBAGA PENELITIAN DAN PENGABDIAN MASYARAKAT (LPPM) UNIVERSITAS BUANA PERJUANGAN KARAWANG}

\author{
PENINGKATAN SUMBER DAYA MANUSIA MELALUI INSTRUMEN \\ PENGADAAN BUKU PERPUSTAKAAN \\ asepjamaludin@ubpkarawang.ac.id \\ wanta@ubpkarawang.ac.id \\ yudifirmansyah@ubpkarawang.ac.id
}

\begin{abstract}
Abstrak
Paktor Sumber daya manusia (SDM) selain modal adalah sangat penting dalam mengelola suatu organisasi. Oleh sebab itu, sumber daya manusia harus dikelola dengan baik untuk meningkatkan tata kelola organisasi, sebagai salah satu pungsi dalam perusahaan atau organisasi yang dikenal dengan manajemen sumber daya manusia (MSDM). Peningkatan sumber daya manusia harus ditingkatkan baik di daerah pedesaan maupun daerah perkotaan. Fokus bahasan ini adalah Bagaimana pengembangan sumber daya manusia di pedesaan dengan melalui insrtmen pengadaan buku perpustakaan di Desa. Karena pedesaan merupakan penopang ekonomi perkotaan. Apabila sumber daya manusia yang ada di desa meningkat itu bisa menjadi penopang bagi perkembangan di kota. Dengan adanya perpustakaan di desa akan membantu dalam penguasaan ilmu pengetahuan dan teknologi. Dengan harapan jika sumber daya manusia meningkat baik di perkotaan maupun pedesaan, maka Negara Indonesia yang termasuk dalam negara berpenduduk banyak di dunia akan maju dan menjadi negara yang makmur dan sejahtera

Pepustakaan merupakan unit pelayanan, instansi, tempat, gedung, ruangan dimana terdapat kumpulan atau koleksi bahan perpustakaan. Perpustakaan sendiri bisa dilaksanakan dimana saja selama ada bahan pustaka, pustakawan dan pemustakanya. Dalam aturan/undand-undang disebutkan bahwa gerakan nasional gemar membaca dilaksanakan oleh Pemerintah dan pemerintah daerah dengan melibatkan seluruh masyarakat. Selain itu juga pemerintah daerah sampai ke kecamatan dan desa juga berperan dalam membantu pemerintah dalam mencerdaskan masyarakat.
\end{abstract}

Oleh karena itu, minat baca masyarakat perlu ditingkatkan dengan adanya perpustakaan desa. Perlunya mem bangkitkan dan meningkatkan minat baca 20 | Jurnal Buana Pengabdian 
masyarakat secara merata di berbagai daerah sehingga tercapai masyarakat yang cerdas yang selalu mengikuti perkembangan ilmu pengetahuan dan teknologi. Perpustakaan desa enjadi sebuah wadah kegiatan belajar masyarakat terutama yang keluarga nya kekurangan ekonomi dan mendukung peningkatan kemampuan aksarawan baru dalam pemberantasan buta aksara sehingga tidak menjadi buta aksara kembali.

Pemerintah desa dalam penyelenggara pemerintahanny untuk mendukung pembangunan secara menyeluruh perlu dilengkapi dengan pasilitas-pasilitas yang mendukung terhadapat pembangunan terutamana pembangunan Desa . Tujuannya untuk memenuhi kebutuhan dan memberikan pelayanan yang diperlukan oleh masyarakat. Salah satu cara untuk meningkatkan pengetahuan dan kesejahteraan masyarakat yaitu dengan dibentuknya perpustakaan. Program perpustakaan desa merupakan program yang dilaksanakan oleh pemerintah yang mengacu pada” Undang-Undang Republik Indonesia Nomor 43 Tahun 2014. Pembuatan perpustakaan terutama di desa-desa di seluruh wilayah Indonesia itu adalah untuk mendukung upaya pemerintah mengembangkan kehidupan masyarakat dan peningkatan sumber daya yang ada di masyarakat terutama".

Kata Kunci : Manajemen Sumber Daya Manusia, Perpustakaan 


\begin{abstract}
Factors Human resources (HR) in addition to capital is very important in managing an organization. Therefore, human resources must be managed properly to improve organizational governance, as one of the functions in a company or organization known as "human resource management" (HRM). Increasing human resources must be improved both in rural areas and urban areas. The focus of this discussion is How to develop human resources in rural areas through the procurement of library books in the village. Because the countryside is the backbone of the urban economy. If the human resources in the village increase it can be a pillar for development in the city. Having a library in the village will help in mastering science and technology. With the hope that if human resources increase in both urban and rural areas, the Indonesian nation which is included in the world's most populous country will advance and become a prosperous and prosperous country.

Library is a service unit, agency, place, building, room where there is a collection or collection of library materials. The library itself can be carried out anywhere as long as there are library materials, librarians and librarians. In the rules / regulations it is stated that the national reading movement is carried out by the Government and the regional government by involving the entire community. In addition, local governments to the sub-districts and villages also play a role in helping the government in educating the community.

Therefore, public interest in reading needs to be increased by the existence of village libraries. The need to arouse and increase public interest in reading evenly in various regions so as to achieve an intelligent society that always follows the development of science and technology. The village library became a place for community learning activities especially those whose families lacked economics and supported the improvement of new literacy skills in eradicating illiteracy so that they did not become illiterate again.

The village government as the organizer of government, development, and society needs to be equipped, facilitated, and supported by the formation of social service institutions and public services. The goal is to meet the needs and provide services needed by the community. One way to increase knowledge and welfare of the community is by establishing a library. The village library program is a program implemented by the government which refers to "Law of the Republic of Indonesia Number 43 of 2014. The establishment of village libraries in all regions of Indonesia is intended to support the government's efforts to develop people's lives".
\end{abstract}

Keywords: Human Resource Management, Library 


\section{Pendahuluan}

Tata cara kegiatan tentang layanan sirkulasi ada dua :

- Sistem terbuka (Open Access), memungkinkan pengguna memilih dan mengambil koleksi di rak secara bebas tanpamelalui petugas.

- Sistem tertutup (Close Access), pengguna didalam memanfaatkan koleksi di rak harus melalui petugas.

Pemasaran atau promosi adalah hal sangat penting yang perlu dikerjakan dalam pengelolaan perpustakaan desa. Promosi bertujuan untuk memfasilitasi komunikasi antara perpustakaan dan calon pengguna. Karena salah satu keberhasilan sebuah perpustakaan adalah dapat dilihat dari tingkat kunjungan pengguna dan pemanfaatan informasi (koleksi) oleh pengguna. Hal yang penting yang harus dipikirkan adalah dukungan dari manajemen, karena promosi mestinya termasuk dalam anggaran perpustakaan dan terintegrasi ke dalam proses perencanaan perpustakaan .Fungsi dan yang paling penting dalam mengelola Perpustakaan Desa/Kelurahan adalah melayani masyarakat secara khusus di Desa Puseur Jaya adalah dengan tersedianya buku bacaan yang disesuaikan dengan kebutuhan dan kondisi dari masyarakat. Selain itu juga Perpustakaan Desa harus mampu memenuhi kebutuhan secara berkesinambungan dengan perkembangan jaman . Baik kebutuhan informasi yang bersifat ilmu pengetahuan, berita, maupun informasi lainnya yang telah berkembang /menyebar di masyarakat secara umum. Hasil dan pembahasan. Dibawah ini adalah beberapa hal harus dilakukan dalam pengelolaan perpustakaan desa :

$\checkmark$ Peningkatan Sumber Daya Manusia

$\checkmark$ Jumlah atau literatur

$\checkmark$ Pelayanan

$\checkmark$ Promosi untuk memasarkan tentang tata kelola adminstrasi dalam pengelolaan perpustakaan.

Hal ini akan mempermudah perpustakaan dalam memberikan apa yang menjadi tuntutan dan kebutuhan pemakainya. Menurut Sumardji (1998:83) Staffing atau pengisian jabatan didefinisikan sebagai pengisian jabatan dalam 
struktur organisasi dengan cara mengidentifikasikan kebutuhan tenaga kerja, mendaftar tenaga kerjayang ada, merekrut, memilih, menempatkan, promosi, menilai, memberi imbalan dan melatih orang yang diperlukan . Fungsi staffing ini juga sangat erat kaitannya dengan fungsi pengorganisasian. Proses pengolahan dalam perpustakaan khusus pada prinsipnya tidak jauh berbeda dengan perpustakaan pada umumnya. Proses administrasi dan tata kelola perpustakaan harus memperhatikan judul buku yang terbaru, ketersediaan buku bacaan dan bagaimana suasana runga baca yang nyaman dan sistem pengembalian buku. Jenis atau ruang lingkup perpustakaan harus disesuaikan dengan jenis perpustakaan contahnya :

a. Tata kelola perpustakaan yang ada di Perpustakaan memiliki fungsi sebagai lembaga pelayanan informasi, bertindak sebagai penghubung antara dua dunia, yaitu masyarakat sebagai pengguna dan sumber-sumber informasi, baik cetak maupun non cetak. Oleh karena itu setiap bahan pustaka atau informasi yang dibutuhkan oleh pengguna sedapat mungkin harus disediakan oleh perpustakaan. Disamping itu perpustakaan harus mampu menjamin bahwa setiap informasi atau koleksi yang berbentuk apapun mudah diakses oleh semua masyarakat yang memerlukan.Agar informasi atau bahan pustaka Sutarno (2004 : 45) menjelaskan bahwa di perpustakaan dapat dimanfaatkan atau diketemukan kembali dengan mudah, maka dibutuhkan system pengelolaan dengan baik dan sistematis yang biasa disebut dengan kegiatan pengolahan (processing of library materials) atau pelayanan teknis (technical service) . Kegiatan pengolahan bahan pustaka di perpustakaan biasanya mencakup beberapa kegiatan : Pembinaan dan pengembangan koleksi, Inventarisasi, Katalogisasi, Klasifikasi, dan Kelengkapan fisik buku .

b. Pengembangan Koleksi Pengembangan koleksi (Collection development) merupakan serangkaian proses atau kegiatan yang bertujuan mempertemukan kebutuhan pemakai dengan rekaman informasi dalam lingkungan perpustakaan yang mencakup kegiatan : penyusunan kebijakan 
pengembangan koleksi, pemilihan koleksi, pengadaan koleksi, penyiangan koleksi, serta evaluasi pendayagunaan koleksi . Pengadaan buku di perpustakaan yang telah dimiliki oleh perpustakaan adalah dengan cara membeli buku yang baru, pinjam, pemberian dari donatur atau para relawan yang peduli dengan perpustakaa, sedangkang proses peminjaman dan pemasuka buku harus dicatat ke dalam buku induk atau buku inventarisasi perpustakaan. Proses ini adalah untuk memudahkan dalam pencatatan dan pemutahiran data buku yang ada di perpuskaan. Perpustakaan sebagai suatu system informasi berfungsi menyimpan pengetahuan dalam berbagai bentuk serta pengaturannya sedemikian rupa, sehingga informasi yang diperlukan dapat diketemukan kembali dengan cepat dan tepat. Sistem manajemen pengelolaan perpustakaan ini dilakukan akan memberikan kenyamanan dan tertib administrasi dalam pengeloaan adminstrasi perpustakaan secara keseluruhan.

\section{Kesimpulan dan saran}

Peran perpustakaan desa sangat sentral dalam membina dan menumbuhkan kesadaran membaca. Kegiatan membaca tidak bisa dilepaskan dari keberadaan dan tersedianya bahan bacaan yang memadai baik dalam segi jumlah maupun dalam kualitas bacaan”. Peran tokoh masyarakat sangat penting untuk menggerakkan atau menjadi contoh dalam menumbuh kembangkan minat baca di perpustakaan. 


\section{Daftar Pustaka}

Ansor, Sokhibul. 2007.Perawatan Bahan Pustaka Perpustakaan Sekolah . Jurnal Perpustakaan Sekolah. Hermawan,Rachman dan Zulfikar Zen, 2006, Etika Kepustakawanan . Jakarta:Sagung SetoPurwono. 2010.

Kerja Sama Dan Jaringan Perpustakaan. Jakarta: UniversitasTerbuka . Rahayuningsih, 2007.

Pengelolaan Perpustakaan.Yogyakarta: Graha Ilmu . Sulistyo-Basuki. 1993.Pengantar Ilmu Perpustakaan, Jakarta: Gramedia PustakaUtama.Sumardji.

1998.Perpustakaan: Organisasi dan Tata Kerjanya . Jakarta: Kanisius.Sutarno NS. 2004. Manajemen

Perpustakaan : Suatu Pendekatan Praktik. Jakarta:Sagung Seto . 